\title{
Effect of Environmental Taxes as Correcting Negative Externalities Caused by Water Pollution Applied to the Agro-Food Industry
}

\author{
I. M. Román-Sánchez ${ }^{1,2}$, Irene Carra ${ }^{2,3}$ \\ ${ }^{1}$ Department of Applied Economics, University of Almería, Almería, Spain \\ ${ }^{2}$ CIESOL, Joint Centre of the University of Almería-CIEMAT, Almería, Spain \\ ${ }^{3}$ Department of Chemical Engineering, University of Almería, Almería, Spain \\ Email: iroman@ual.es, irenecarra@ual.es
}

Received April 10, 2013; revised May 10, 2013; accepted June 10, 2013

Copyright (C) 2013 I. M. Román-Sánchez, Irene Carra. This is an open access article distributed under the Creative Commons Attribution License, which permits unrestricted use, distribution, and reproduction in any medium, provided the original work is properly cited.

\begin{abstract}
Market failure involving pollution from wastewater discharges industrials, is corrected with the establishment of environmental taxes. Heterogeneity in the design of these taxes, with a different tax base for each EU member country, affects both the pollution parameters considered and their weight in the calculation of the tax payable. This paper presents a study on the variety of this tax in Belgium, Italy and Spain. Finally, we discuss the possibility of the same as correcting market failure.
\end{abstract}

Keywords: Sanitary Tax; Wastewater; Externalities; Environmental Taxes; Agro-Food Industry

\section{Introduction}

Society's concern about environment increases, encouraging Governments to take measures which allow conserving natural spaces [1]. The Water Framework Directive (WFD) (Directive 2000/60/EC) [2] has encouraged water protection and management policies and water pollution decrease. Article 4 of said Directive deals with the environmental objectives for surface water and the necessary steps to progressively reduce contamination as well as wastewater discharges.

The economical definition of "pollution" varies depending on its effects on the environment (e.g. species extinction, rivers and aquifers excessive exploitation, public health damages, epidemics, etc.) as well as human behaviour with regard to said effects which, generally speaking, are manifested as welfare loss. In this sense, the economical concept of "pollution" is usually defined as the negative externality or market failure, or the situation in which the pollutant activity provokes another agent's welfare loss. Pollution, understood as market failure, involves an environmental quandary which justifies governmental intervention. Said intervention can be carried out through market instruments (taxes and pollution transferable rights).
Environmental taxes give place to constant technological stimuli since they involve savings on the tax cost itself, provided that the agents introduce pollution reducing behaviors. Thus, every contaminating agent adapts its actions to pay for polluting or to invest in technology which contaminates less, paying the least possible amount of these taxes.

As the problem of pollution could be approached through a technological change which allows productive processes and economical activities decontamination, leading part of the environmental revenue by means of a green fiscal reform is recommended. Indeed, environmental taxation generates incentives to stop pollutant processes and investments in clean technologies [3].

This paper deals with the role of sanitary tax as a tool to encourage investment on new technologies of wastewater treatment to correct negative externalities provoked by agrofood industry water pollution. In this sense, sanitary taxes belonging to three Spanish regions (Cantabria, Cataluña and Valencia), to Belgium (Brussels) and to Italy (Caserta) are studied. Wastewater from a tomatoprocessing industry was chosen as a model as well as the same wastewater decontaminated in-situ before discharging. Thus, we analyse the taxable base and water 
pollution parameters contemplated to penalize the pollutant agent. Finally, profitability of investing in water treatment depending on the sanitary tax is analysed.

\section{Agrofood Industry}

Agrofood industry is the main manufacturing European activity, representing $16 \%$ of total invoice with 956,000 million euros. The European Union counts with over 274,000 companies in EU-27, being most of them small businesses with less than 250 workers $(99.1 \%$ of the total). It creates 4.1 million jobs, representing $48.7 \%$ of the complete agrofood industry production in the EU.

The use of water in food businesses is essential to the development of productive activities. Total consumption in European agrofood industries may vary between $8 \%$ and $15 \%$ of total industry consumption, which means $1 \%$ - $1.8 \%$ of consumed water in Europe. Water is used in agrofood industry as cooling agent, for cleaning and disinfecting and in the process itself. This means up to $70 \%$ of company consumption [4].

Water is a key resource, but limited. Great consumption and its disposal after using it lead to new technological, social, economic and environmental questions which significantly affect sustainability. Improvement in water management results in a decrease in associated costs (energy, sanitary tax, consumption, wastewater treatment, etc.), reaching important savings. Availability of this resource, increase in costs and other related effects are factors to bear in mind. As a result, water saving and its reuse are actions to carry out to increase competetiveness. A clear example is sugar industry in the EU: sugar beet contains $75 \%$ water. This water is extracted during the process and reused for washing, extracting and crystallization several times. Reuse is such that $90 \%$ of the organic matter is removed before discharging.

Among the three economic sectors, agriculture is the one which uses more water. Data from Aquastat [5] indicate that water consumed for agriculture uses represent up to $48 \%$ total consumed water in Mediterranean European countries (Spain, Italy, Greece) versus northern European countries (1.3\%) (Denmark, Finland, Norway, Sweden). This difference is due to diversity in soil and weather, which implies that in southern Europe irrigation water comes mainly from the underground (blue water); while in the north water is used mainly from the rain (green water). All this, added to water scarcity, wrong management, inefficient irrigation practices, evaporation and pollution threat water availability. As for agrofood industry, raw materials come from agriculture. Thus, elaborated products involve higher water consumption: firstly, water from crop irrigation and then, water consumed in the industry itself (water footprint of the product).
Different solutions are currently being proposed to stop or decrease water stress. Improvement in agriculture techniques, wastewater treatments or reuse are some of the practices governments should focus on. In this regard, environmental taxes have an important role. FAO general director, José Graziano da Silva informed that "agriculture is the key for water sustainable use" [6]. Despite improvements in many regions, water pollution in agriculture is the main cause of bad water quality in many European regions due to the presence of nutrients (nitrogen and phosphorus) and pesticides.

\section{The Sanitary Tax Structure}

In compliance with Article 4 in the WFD, the member states have developed environmental taxes which levy wastewater discharges. They are known as sanitary taxes (STs) and each country has a specific design. STs are destined to fund public wastewater treatments, from installation investments to operating and maintenance costs. In Europe this fee falls to local governments. The study of the STs belonging to the five selected regions revealed there are great variations in structure as well as the pollution parameters considered in each norm, which result in marked differences in the payable tax amount (Table 1).

The taxable base has two terms: firstly, a fixed cost, which is independent of the discharged volume; secondly, a variable term dependent on the discharged wastewater volume and pollution level. To characterize the discharged wastewater, pollution load is measured by considering different parameters for each ST: chemical oxygen demand (COD) and suspended solids (SS), which are regarded in all the studied cases; conductivity (C); biological oxygen demand (BOD); nutrient concentrations (total nitrogen, $\mathrm{N}$, and phosphorus, $\mathrm{P}$ ); and inhibitory substances (IS). COD, N, P and SS are considered in all five regions. In Table 2, the parameters considered in each region are included.

\section{Sanitary Tax Analysis}

To compare the ST of the five studied regions (Cantabria, Cataluña, Valencia, Caserta and Brussels), the different ST structures were applied to wastewater generated in a tomato-processing industry and to the same water treated in-situ by a common biological treatment to fulfill legal discharge requirements [12]. In Table 3, the chemical and physical properties of raw and treated wastewater are presented [13]. The biological treatment allows reducing pollution load considerably. For instance, chemical oxygen demand, nitrogen and phosphorus concentrations, which are three pollution parameters present in all ST structures, and important to the final ST amount, are rather reduced thanks to the biological treatment. Thus, the decontaminated effluent would be discharged instead 
Table 1. Sanitary taxes belonging to the five studied regions.

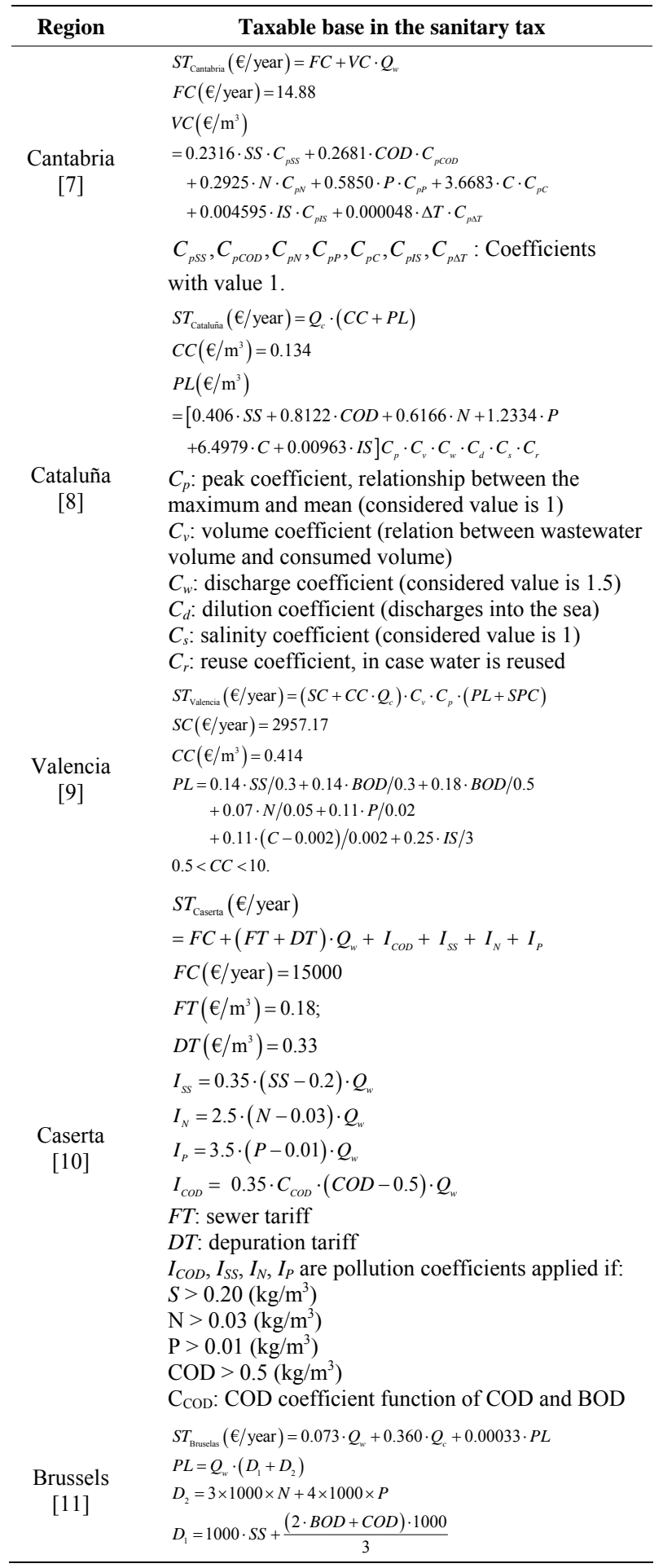

of the raw wastewater, so the environment would be less damaged.

Each studied ST was applied using the characteristics of raw and treated wastewater. For this purpose, a discharged volume of $36,500 \mathrm{~m}^{3} /$ year, corresponding to 100 $\mathrm{m}^{3} /$ day, was considered as basis of calculation. The cal-
Table 2. Pollution parameters.

\begin{tabular}{cccccccc}
\hline \multirow{2}{*}{ Region } & \multicolumn{7}{c}{ Pollution parameters } \\
\cline { 2 - 8 } & COD & N & P & C & BOD & SS & IS \\
\hline Cantabria & $\mathrm{x}$ & $\mathrm{x}$ & $\mathrm{x}$ & $\mathrm{x}$ & & $\mathrm{x}$ & $\mathrm{x}$ \\
Cataluña & $\mathrm{x}$ & $\mathrm{x}$ & $\mathrm{x}$ & $\mathrm{x}$ & & $\mathrm{x}$ & $\mathrm{x}$ \\
Valencia & $\mathrm{x}$ & $\mathrm{x}$ & $\mathrm{x}$ & $\mathrm{x}$ & $\mathrm{x}$ & $\mathrm{x}$ & $\mathrm{x}$ \\
Caserta & $\mathrm{x}$ & $\mathrm{x}$ & $\mathrm{x}$ & & & $\mathrm{x}$ & \\
Brussels & $\mathrm{x}$ & $\mathrm{x}$ & $\mathrm{x}$ & & $\mathrm{x}$ & $\mathrm{x}$ & \\
\hline
\end{tabular}

$\mathrm{x}$ denotes that the pollution parameter is considered in the equation for calculating the tax amount.

Table 3. Chemical-physical wastewater parameters

\begin{tabular}{ccccccc}
\hline \multirow{2}{*}{ Water } & \multicolumn{6}{c}{ Water characteristics $\left(\mathbf{k g} / \mathbf{m}^{3}\right)$} \\
\cline { 2 - 8 } & $\mathbf{C O D}$ & $\mathbf{N}$ & $\mathbf{P}$ & $\mathbf{C}(\mathbf{S} / \mathbf{c m})$ & $\mathbf{B O D}$ & SS \\
\hline Raw wastewater & 1.58 & 0.036 & 0.015 & 0.002 & 0.4 & 0.05 \\
Treated water & 0.013 & 0.014 & 0 & 0.002 & 0.005 & 0.05 \\
\hline
\end{tabular}

culated payable ST for them in each region is shown in Table 4.

In this sense, significant differences can be observed not only among the regions in the payable ST, but also between raw and treated wastewater. The difference among regions is due to the diverse applicable laws. Thus, the average ST amount for raw wastewater is $38377.85 € /$ year, being the highest value for Cataluña (79201.55 €/year) and the lowest for Valencia (16472.75 $€ /$ year) despite including all pollution parameters in the ST structure (Table 2). Cantabria and Valencia present rather similar ST amounts and, together with Brussels, they are below the calculated average ST amount. On the other hand, Cataluña and Caserta are well over the mean.

Regarding the treated wastewater, the average ST amount obtained is $12848.94 € /$ year. Also, the lowest ST amount was found for Cantabria (982.02 €/year), as for raw wastewater. This value is over 34 times lower than amount which would be paid in Caserta. However, in Valencia the amount rises to 9.034.09 €/year, while for raw wastewater Cantabria and Valencia presented similar ST amounts. This is due to the heterogeneity found in the taxable bases and the weight each region gives to the different pollution parameters.

The important reduction in the sanitary tax amount for raw and treated wastewater can lead to a company's investment in wastewater treatment. Nonetheless, this decision depends on the ST itself (consequently, the region the industry is settled) and the water treatment. Although biological treatments are well-established processes, the dissimilarities in wastewater properties from one industry to the next result in varying water treatment costs as well. Indeed, a case by case study is recommended for each company as the aforementioned differences will result in profitable or non-profitable wastewater treatment. Thus, 
Table 4. Payable ST amount.

\begin{tabular}{ccc}
\hline Region & $\begin{array}{c}\text { Raw wastewater } \\
(\boldsymbol{€} / \text { year })\end{array}$ & $\begin{array}{c}\text { Treated wastewater } \\
(\boldsymbol{€} / \text { year })\end{array}$ \\
\hline Cantabria & 16871.30 & 982.02 \\
Cataluña & 79201.55 & 7764.65 \\
Valencia & 16472.75 & 9034.09 \\
Caserta & 51357.65 & 33615.00 \\
Brussels & 27986.01 & 17004.99 \\
\hline
\end{tabular}

if the ST amount payable for raw wastewater discharge is higher than the payable amount due to water treatment and ST amount due to treated wastewater discharge, depuration technologies in the industry are encouraged.

\section{Conclusions}

The productive process carried out in agrofood industry requires high water volume, which is returned to the environment. This water is often polluted. For this reason, when discharged water is polluted, the lack of investment on water treatments results in environmental detriment.

In this context, the present study about STs in Spain, Italy and Belgium show the need to homogenize their structure in order to optimize their application and encourage water technologies when necessary. Specifically, heterogeneity in the ST design involves differences in the payable amount as well as in the importance given to pollution present in wastewater.

Companies' decision on water treatment depends on the ST amount as well as treatment cost. In order to meet the objective of correcting market failure, in no case should the ST be lower than in-situ treatment cost. Otherwise, treatment costs would be transferred to society, who is the one who finances public wastewater treatment.

\section{Acknowledgements}

This research was supported by the Ministerio de Economía y Competitividad (CTQ2010-20740-C03-01/PPQ), the European Regional Development Fund (ERDF). Irene Carra would like to acknowledge the Ministerio de Educación, Cultura y Deporte for her FPU scholarship (AP2010-3218).

\section{REFERENCES}

[1] M. Jiménez and R. Lafuente, "La Conciencia Ambiental:
Qué es y Como Medirla," IX Congreso Español de Sociología, Grupo de Trabajo 21: Sociología y Medio Ambiente, Barcelona, 13-15 September 2007.

[2] Directiva 2000/60/CE del Parlamento Europeo y del Consejo, de 23 de Octubre de 2000 por la que se Establece un Marco Comunitario de Actuación en le Ámbito de la Política de Aguas. Diario Oficial de las Comunidades Europeas L 327 de 22-12-2000.

[3] X. Labandeira, "El futuro de la Imposición Ambiental," en Papeles de Economía Española, No. 125/126, (Ejemplar Dedicado a: Claves Actuales de la Fiscalidad del Futuro), 2010, pp. 308-311.

[4] Food Drink Europe, "Environmental Sustainability Visión towards 2030. Acievements, Challenges and Opporunities," 3rd Edition, 2012. www.fooddrinkeurope.eu

[5] FAO, "Base de datos AQUASTAT, Organización de Naciones Unidas Para Alimentos y Agricultura (FAO)," 2013.

[6] J. G. da Silva, "FAO General Director. La Semana Mundial de Agua," 27 de agosto de 2012, Estocolmo.

[7] Boletín oficial de Cantabria, Ley 2/2002, de 29 de abril, de saneamiento y depuración de las aguas residuales de la comunidad autónoma de Cantabria, No. 86, 2002, pp. 4275-4287.

[8] Diario oficial de la Generalitat de Cataluña, Decreto Legislativo 3/2003, de 4 de noviembre, de aguas de Cataluña, No. 4015, 2003, pp. 22823-22840.

[9] Boletín oficial del Estado, Ley 2/1992, de 26 de marzo, de saneamiento de las aguas residuales de la Comunidad Valenciana, No. 128, 1992, pp. 18195-18199.

[10] Consiglio di Amministrazione, Regolamento servicio fognatura e depurazione. Consorzio idrico Terra de Lavoro, Approvato dal C.d.A., 2010. Delibera n. 293 del 07-12-2010.

[11] Le Moniteur Belge, "Contrat de Gestion Entre le Gouvernement de la Region de Bruxelles-Capitale et la Société bruxelloise de Gestion de l'Eau (SBGE)," Modalités d'estimation et d'application des prix unitaires d'asseinissement, Ed. 2, 2008, pp. 17403-17422.

[12] R. D. Law, "Boletín oficial del Estado, Real Decreto Legislativo $1 / 2001$, de 20 de julio, por el que se aprueba el texto refundido de la Ley de Aguas," No. 176, 2001, pp. 26791-26817.

[13] Z. D. Xu, G. Nakhla and J. Patel, "Characterization and Modeling of Nutrient-Deficient Tomato-Processing Wastewater Treatment Using an Anaerobic/Aerobic System," Chemosphere, Vol. 65, No. 7, 2006, pp. 1171-1181. doi:10.1016/i.chemosphere.2006.03.063 


\section{Nomenclatures}

\begin{tabular}{cl}
\hline$\Delta \mathrm{T}$ & temperature difference $\left({ }^{\circ} \mathrm{C}\right)$ \\
BOD & biological oxygen demand $\left(\mathrm{kg} / \mathrm{m}^{3}\right)$ \\
$\mathrm{C}$ & conductivity $(\mu \mathrm{S} / \mathrm{cm})$ \\
$\mathrm{COD}$ & chemical oxygen demand $\left(\mathrm{kg} / \mathrm{m}^{3}\right)$ \\
$\mathrm{CC}$ & consumption cost $\left(€ / \mathrm{m}^{3}\right)$ \\
$\mathrm{FC}$ & fixed cost $(€ /$ year $)$ \\
$\mathrm{IS}$ & inhibitory substance \\
$\mathrm{N}$ & total nitrogen $\left(\mathrm{kg} / \mathrm{m}^{3}\right)$ \\
$\mathrm{P}$ & total phosphorus $\left(\mathrm{kg} / \mathrm{m}^{3}\right)$ \\
$\mathrm{PL}$ & pollution load \\
$\mathrm{Q}_{\mathrm{c}}$ & consumed volume per year $\left(\mathrm{m}^{3} / \mathrm{year}\right)$ \\
$\mathrm{Q}_{\mathrm{w}}$ & wastewater volume per year $\left(\mathrm{m}^{3} / \mathrm{year}\right)$ \\
$\mathrm{SC}$ & service cost $(€ /$ year $)$ \\
$\mathrm{SPC}$ & specific pollution coefficient \\
$\mathrm{SS}$ & suspended solids $\left(\mathrm{kg} / \mathrm{m}^{3}\right)$ \\
$\mathrm{ST}$ & sanitary tax $(€ /$ year $)$ \\
$\mathrm{VC}$ & variable cost $\left(€ / \mathrm{m}^{3}\right)$ \\
\hline
\end{tabular}

